\title{
PENGARUH PENERAPAN TEKNOLOGI INFORMASI TERHADAP KINERJA APARATUR NAGARI DALAM PENGELOLAAN KEUANGAN NAGARI
}

\author{
Resfiana \\ Jurusan Ilmu Administrasi Publik, Fakultas Ilmu Sosial,Universitas Negeri Padang \\ Email: resfianarusman96@gmail.com
}

\begin{abstract}
This article discussed the effect of information technology application on performance of Nagari Apparatus in nagari financial management in Tanah Datar District. This research was motivated by indications that there were lack of knowledge and ability of the nagari apparatus in applying information technology in the process of nagari financial management. This study used quantitative methods. The population of this study amounted to 600 people consisting of Walinagaries (village headmasters), Secretaries, Treasurers and five Heads of Nagari Affairs. The samples in this study were 240 respondents which were determined based on Slovin formula with a significant level of 5\%. Sampling in his study was determined with Multistage Random Sampling technique. The data collected through questionnaires using the Likert scale measurement. The analysis of this study used multiple linear regression tests. The results of this study showed that the benefit (utilization) and the ease of use sub-variables partially and simultaneously had significant effects on the performance of the nagari apparatus in financial management in Tanah Datar District.
\end{abstract}

Keywords : Information technology, job performance, nagari financial management

How to Cite: Resfiana. 2019. Pengaruh Penerapan Teknologi Informasi Terhadap Kinerja Aparatur Nagari dalam Pengelolaan Keuangan Nagari. 3(1): pp.91-100. DOI: https://doi.org/10.24036/jess/vol3-iss1

\section{Pendahuluan}

Sejak dikeluarkannya paket kebijakan otonomi daerah yang ditetapkan dengan UU No. 22 dan 25 Tahun 1999 jo UU No. 32 dan 33 Tahun 2004 dimana didalamnya dijelaskan bahwa adanya pelimpahan kewenangan dari pemerintah pusat kepada daerah untuk melakukan kelembagaan serta melaksanakan pengaturan dan pengawasan fiskal secara otonom. Hal ini membawa perubahan yang fundamental dalam hubungan tata pemerintahan dan tata keuangan sekaligus membawa perubahan yang penting khususnya dalam pengelolaan keuangan di daerah. Paket kebijakan otonomi daerah berdasarkan UU No. 22 dan 25 Tahun 1999 jo UU No 32 dan 33 tahun 2004 disusul dengan lahirnya Undang-undang tentang Desa No. 6 Tahun 2014 dimana hal ini melahirkan rezim keuangan baru ditingkat desa yakni dalam hal pengelolaan keuangan dan aset desa. Dimana pengelolaan keuangan desa beriringan dengan atribut kewenangan Undangundang terhadap aparatur di desa. Selanjutnya dalam Peraturan Menteri Dalam Negeri Republik Indonesia Nomor 113 Tahun 2014 Tentang Pengelolaan 
Keuangan Desa dijelaskan bahwa asas-asas yang menjadi pedoman dalam pengelolaan keuangan desa yaitu transparan, akuntabel, partisipatif, serta dilakukan dengan terib dan disiplin anggaran. Hal ini susul berdasarkan Peraturan Daerah Kabupaten Tanah Datar Nomor 3 Tahun 2015 tentang perubahan atas Peraturan Daerah Nomor 4 Tahun 2007 Tentang Pokok-pokok Pengelolaan Keuangan Daerah dimana bahwa proses pengelolaan keuangan nagari mencakup yaitu keseluruhan kegiatan yang meliputi perencanaan, pelaksanaan, penatausahaan, pelaporan dan pertanggungjawaban keuangan desa.

Sesuai dengan intruksi presiden Nomor 3 Tahun 2003 Tentang Kebijakan dan Strategi Nasional Pengembangan E-Government bahwa setiap pimpinan lembaga negara, kepala daerah diamatkan untuk mengambil langkah-langkah yang diperlukan sesuai dengan tugas, fungsi dan kewenangannya dalam terlaksana pengembangan e-government secara nasional. Selanjutnya merujuk berdasarkan Peraturan Bupati Tanah Datar Nomor 44 tahun 2017 tentang Visi Misi badan Keuangan Daerah bahwa terwujudnya pengelolaan keuangan daerah yang transparansi dan akuntabilitas melalui manajemen yang baik dengan menggunakan teknologi informasi. Maka setiap aparatur berupaya untuk dapat meningkatkan efesiensi dan efektifitas penyelenggaraan pemerintahan untuk mewujudkan good governance melalui penyelenggaraan tugas yang transparan dan akuntabel salah satunya dengan memanfaatkan teknologi informasi. Namun dalam hal ini, pada kenyataannya dilapangan ditemukan adanya perosalanpersoalan dalam proses pengelolaan keuangan nagari di Kabupaten Tanah Datar.

Contohnya berdasarkan wawancara dengan Walinagari Aia Angek Kecamatan X Koto bahwa salah satu hal yang menjadi kendala dalam proses pengelolaan keuangan nagari adalah kurangnya jumlah sumber daya manusia yang paham terhadap teknologi informasi dan beberapa fasilitas pendukungnya. Sama halnya dengan Nagari III Koto bahwa yang menjadi masalah dalam proses pengelolaan keuangan nagari adalah kurangnya keterampilan para aparatur nagari dalam penguasaan komputer khususnya pada posisi bendahara. Sementara itu berdasarkan wawancara dengan Walinagari Simawang bahwa hal yang menjadi kendala yaitu kurangnya fasilitas pendukung nagari terutama tersedianya jaringan wifi yang baik. Karena sistem keuagan nagari berbasis aplikasi menuntut akan ketersediaan wifi yang baik dan lancar dan juga sangat dibutuhkan sumber daya manusia yang mampu menjalankan hal tersebut.

Berdasarkan permasalahan yang diuraikan diatas, maka peneliti ingin menguji apakah terdapat pengaruh penerapan teknologi informasi terhadap kinerja aparatur nagari dalam pengelolaan keuangan nagari di Kabupaten Tanah Datar. Penelitian ini merupakan intisari dari hasil penelitian skripsi serta merupakan bagian dari penelitian payung dari Syamsir (2017) yang berjudul Model Pembinaan Aparatur Pemerintahan Nagari dalam Pengelolaan Keuangan Nagari di Kabupaten Tanah Datar. Maka rumusan masalah dapat diuraikan senagai berikut:

1. Apakah terdapat pengaruh kemanfaatan (usefullness) penerapan teknologi informasi terhadap kinerja aparatur nagari dalam pengelolaan keuangan nagari di Kabupaten Tanah Datar? 
2. Apakah terdapat pengaruh kemudahan penggunaan (ease of use) teknologi informasi terhadap kinerja aparatur nagari dalam pengelolaan keuangan nagari di Kabupaten Tanah Datar?

3. Apakah terdapat pengaruh kemanfaatan (usefulness) dan kemudahan penggunaan (ease of use) teknologi informasi terhadap kinerja aparatur nagari dalam pengelolaan keuangan nagari di Kabupaten Tanah Datar?

\section{Tinjauan Kepustakaan}

\section{Teknologi Informasi dan Kinerja}

Menurut Anis (2016) teknologi informasi merupakan bagian dari sistem Informasi dan teknologi informasi ditunjukkan pada teknologi yang digunakan dalam menyampaikan dan mengolah informasi. Sama halnya menurut Hilmi (2016) teknologi informasi adalah seperangkat alat yang membantu seseorang dalam bekerja dengan menggunakan informasi dan melakukan berbagai tugas yang berhubungan dengan proses informasi tersebut. Sementara itu menurut Alfa (2016) teknologi informasi adalah adanya hubungan positif namun tidak signifikan diantara beberapa faktor yaitu faktor sosial, perasaan pengguna (affect), konsekuensi jangka panjang dan kesesuaian tugas dalam pemanfaatan teknologi informasi terhadap kinerja, sedangkan berdasarkan kondisi yang memfasilitasi berpengaruh positif terhadap kinerja individual.

Sementara itu menurut Dimas Ernomo Putra (2015) mengenai faktor-faktor yang dikaitkan dengan pengaruh penerapan teknologi informasi terhadap pekerja ialah salah satu teori yang dikembangkan oleh Fred Davis mengenai prilaku penggunaan dan penerimaan sistem teknologi informasi yang dikenal dengan model Technology Acceptence Model (TAM). Model ini dibuat untuk menganilisis dan memahami faktor-faktor yang mempengaruhi diterimanya penggunaan teknologi informasi dengan memperkenalkan 2 konstruk kunci yaitu kemanfaatan (usefulness) dan kemudahan penggunaan (esae of use) yang memiliki relevancy dalam memperediksi penerimaan teknologi informasi. Sementara itu menurut Indriasari dkk (dalam Azwir dkk, 2007) bahwa pemanfaatan teknologi informasi berpengaruh terhadap nilai informasi pelaporan keuangan yang merupakan bagian dari akuntabilitas kinerja instansi pemerintah / perusahaan ataupun organisasi.

Berdasarkan uraian di atas dapat ditarik kesimpulan bahwa teknologi informasi adalah suatu kombinasi antara teknologi komputer dengan teknologi komunikasi yang digunakan dalam mengolah data yang di dalamnya termasuk memproses, mendapatkan, menyusun, menyimpan, maupun memanipulasi data untuk dapat menghasilkan informasi yang berkualitas dengan melihat 2 konstruk yang berbeda yaitu kemanfaatan dan kemudahan penggunaan teknologi informasi. Maka dalam hal ini konsep inilah yang digunakan dalam penelitian ini.

Selanjutnya kinerja berasal dari kata job performance atau actual performance yang disebut dengan prestasi kerja. Kinerja adalah hasil kerja baik itu secara kualitas maupun kuantitas yang dicapai oleh seseorang dalam melaksanakan tugasnya sesuai dengan tanggung jawab yang diberikan padanya (Mangkunegara, 2011). Sedangkan menurut Pasalong (2008) terdapat 8 faktor 
yang dapat mempengaruhi kinerja seseorang yaitu kompetensi, kemauan, energi, teknologi, kepemimpinan, kopensasi, kejelasan tujuan dan keamanan.

Terdapat penelitian-penelitian yang telah dilakukan oleh para peneliti tentang pengaruh penerapan teknologi informasi terhadap kinerja. Hal ini menunjukkan hasil penelitian yang berbeda-beda, terdapat hasil penelitian yang mendukung teori dan ada yang tidak mendukung atau menentang teori yang ada. Diantara penelitian yang mendukung teori yang ada ialah antara lain dibuktikan oleh penelitian Mohammad Dian Fajri (2011), Ririn Wiseliner (2013), Putu Pande Yudiastra (2015), Desak Made Arisuniarti (2016), Anis Nurlaili (2016), Mutia Sari dkk (2017) yang mana pada umumnya menunjukan bahwa peningkatan kinerja dipengaruhi oleh teknologi informasi. Sementara itu hasil penelitian yang yang tidak mendukung atau menentang akan teori yang ada ialah antara lain dibuktikan oleh penelitian Azwir Nazir dkk (2010) dan Rofika Dan Ardiato (2014) yang membuktikan bahwa teknologi informasi tidak berpengaruh terhadap kinerja.

\section{Pengelolaan Keuangan Desa/Nagari dan Aparatur Nagari}

Sejak lahirnya Undang-undang tentang desa yang telah diundangkan pada 15 Januari 2014 hal ini melahirkan rezim keuangan negara baru di tingkat desa yakni dalam hal pengelolaan keuangan dan aset desa. Berdasarakan Undang-Undang Nomor 6 Tahun 2014 Tentang Desa dijelaskan bahwa keuangan desa adalah semua hak dan kewajiban desa yang dapat nilai dengan uang serta segala sesuatu yang berupa uang dan barang yang berhubungan dengan pelaksanaan hak dan kewajiban desa. Selanjutnya menurut Suragih (dalam sri maulidyah, 2016) keuangan desa/nagari ialah dicerminkan dalam bentuk Anggaran Pendapatan dan Belanja Desa (APBDesa), dimana terdapat minimal 2 pos yang berpengaruh yaitu Pos Pendapatan dan Pos Belanja (Pengeluaran).

Secara umum pengelolaan keuangan desa/nagari diatur berdasarkan Peraturan Menteri Dalam Negeri Republik Indonesia No. 37 Tahun 2007 tentang Pedoman Pengelolaan Keuangan Desa/ Nagari dan berdasarkan Peraturan Daerah Kabupaten Tanah Datar Nomor 3 Tahun 2015 tentang Perubahan atas Peraturan Daerah Nomor 4 Tahun 2007 Tentang Pokok-pokok Pengelolaan Keuangan Daerah dimana di dalamnya dijelaskan bahwa pengelolaan keuangan desa/nagari adalah keseluruhan kegiatan yang meliputi perencanaan, pelaksanaan, penatausahaan, pelaporan dan pertanggungjawaban keuangan desa/nagari. Sama halnya berdasarkan Peraturan Bupati Tanah Datar Nomor 11 Tahun 2014 tentang Pedoman Pengelolaan Keuangan Nagari yang menjelaskan bahwa keuangan nagari adalah semua hak dan kewajiban nagari yang dinilai dengan uang serta segala sesuatu baik berupa uang atau barang yang dapat dijadikan milik Nagari yang berhubungan dengan pelaksanaan hak dan kewajiban nagari. Dalam proses pengelolaan keuangan nagari tertuang asas-asas pengelolaan keuangan nagari yang tertuang dalam Permendagri Nomor 113 Tahun 2014 tentang Pengelolaan Keuangan Desa yaitu transparan, akuntabel, partisipatif, tertib dan disiplin anggaran

Selanjutnya dalam menjalankan Pengelolaan keuangan desa atau nagari berdasarkan pada asas-asas pengelolaan keuangan desa /nagari maka ditetapkan pelaksaan teknis pengelolaan keunagan desa/nagari seperti yang tertuang 
berdasarkan Permendagri Nomor 113 Tahun 2014 tentang Pengelolaan Keuangan Desa/Nagari menyebutkan bahwa kekuasaan Pengelolaan Keuangan Desa/nagari yaitu Kepala Desa/ Nagari. Dalam hal pengelolaan keuangan desa/nagari Kepala desa/nagari menunjuk perangkat nagari sebagai Pelaksana Teknis Pengelolaan Keuangan Nagari (PTPKN) sebagaimana berdasarkan Peraturan daerah Kabupaten Tanah Datar Nomor 4 tahun 2008 Tentang Nagari menjelaskan bahwa perangkat nagari adalah unsur penyelenggara pemerintahan nagari bersama dengan walinagari sebagai pimpinan pemerintah nagari. Perangkat nagari terdiri dari Sekretaris Nagari, Bendahara Nagari dan Kepala Seksi atau Kepala Urusan.

\section{Metode Penelitian}

Jenis penelitian yang digunakkan dalam penelitian ini adalah jenis kuantitatif. Metode pengumpulan data diperoleh berdasarkan kusioner. Populasi dari penelitian ini adalah seluruh aparatur nagari di Kabupaten Tanah Datar berjumlah 600 orang. Sampel dari penelitian ini sebanyak 240 orang yang tentukan berdasarkan rumus slovin dan teknik pengambilan sampel menggunakan teknik multi stage random sampling.

Pengumpulan data penelitian ini menggunakan angket dengan model pengukuran skala likert dengan menggunakan 4 obsi jawaban (point 4 sangat setuju, point 3 Setuju, point 2 tidak setuju, point 1 Sangat Tidak Setuju). Analisis yang digunakan dalam mengolah data penelitian ini ialah menggunkan teknik analisis regresi linear berganda berdasarkan olahan data menggunakan program SPSS (Statistic Programme for Social Science) versi 20.0

\section{Hasil Penelitian dan Pembahasan}

Berdasarkan rumusan masalah yang telah dijelaskan sebelumnya pada bagian pendahuluan yaitu yang terdiri dari 3 rumusan masalah ialah apakah terdapat pengaruh kemanfaatan (usefulness) teknologi informasi terhadap kinerja aparatur nagari dalam pengelolaan keuangan nagari di Kabupaten Tanah Datar?, apakah terdapat pengaruh kemudahan penggunaan (ease of use) teknologi informasi terhadap kinerja aparatur nagari pengelolaan keuangan nagari di Kabupaten Tanah Datar?, apakah terdapat pengaruh kemanfaatan (usefulness) dan kemudahan penggunaan (ease of use) teknologi informasi terhadap kinerja aparatur nagari dalam pengelolaan keuangan nagari di Kabupaten Tanah Datar?. Maka berdasarkan hasil pengumpulan data dari aparatur nagari dalam pengelolaan keuangan nagari dapat dilihat hasil analisis data berdasarkan penelitian yang telah dilakukan. Hasil uji analisis linear berganda pada penelitian dapat digambarkan sebagai berikut: 
Tabel 1. Pengaruh Variabel Teknologi Informasi secara simultan terhadap Kinerja Aparatur Nagari dalam Pengelolaan Kaeuangan Nagari

Model Summary

\begin{tabular}{lrrrrr}
\hline Model & R & R Square & $\begin{array}{c}\text { Adjusted R } \\
\text { Square }\end{array}$ & $\begin{array}{l}\text { Std. Error of } \\
\text { the Estimate }\end{array}$ & Durbin-Watson \\
\hline & & & & & \\
1 & $.318^{\mathrm{a}}$ & .101 & .094 & .33020 & 1.809 \\
\hline
\end{tabular}

a. Predictors: (Constant), rata-rata kemudahan, rata-rata kemanfaatan

b. Dependent Variable: rata-rata pengelolaan keuangan

Tabel 2. Hasil Uji Anova (F) Pengaruh Variabel Teknologi Informasi terhadap Kinerja Aparatur Nagari dalam Pengelolaan Keuangan Nagari

ANOVA $^{\mathrm{a}}$

\begin{tabular}{llllllll}
\hline \multirow{2}{*}{ Model } & & \multicolumn{9}{c}{$\begin{array}{c}\text { Sum of } \\
\text { Squares }\end{array}$} & df & Mean Square & F & Sig. \\
& & & & & & \\
\hline \multirow{2}{*}{1} & Regression & 2.998 & 2 & 1.499 & 13.746 & $.000^{\mathrm{b}}$ \\
& Residual & 26.714 & 245 & .109 & & \\
& Total & 29.711 & 247 & & & \\
\hline
\end{tabular}

a. Dependent Variable: rata-rata pengelolaan keuangan

b. Predictors: (Constant), rata-rata kemudahan, rata-rata kemanfaatan

Berdasarkan hasil analisis regresi pada Tabel 1 di atas dapat di lihat nilai Adjusted R Square yaitu sebesar 0,094 artinya bahwa pengaruh teknologi informasi pada 2 variabel secara simultan terhadap kinerja aparatur nagari dalam pengelolaan keuangan nagari di Kabupaten Tanah Datar diperoleh sebesar 9,4 \%. Dapat dilihat bahwa sisa dari hasil regresi ini yaitu sebesar 99,06 \% yang dipengaruhi oleh faktor lain. Sementara itu di lihat dari hasil uji Anova pada tabel 2 di atas menunjukkan angka signifikan pengaruh yaitu angka $0,000^{\mathrm{b}}$ yang artinya bahwa hasil dari uji regresi ini dapat dipercaya hingga $100 \%$ kebenarannya.

Tabel 3. Pengaruh Sub Variabel Kemanfaatan (usefulness) dan Kemudahan Penggunaan (ease of use) secara parsial terhadap Kinerja Aparatur Nagari dalam Pengelolaan Keuangan

\begin{tabular}{lclll}
\multicolumn{1}{c}{ Sub Variabel } & $\mathbf{R}$ & \multicolumn{1}{c}{ R Square } & $\begin{array}{c}\text { Adjusted R } \\
\text { Square }\end{array}$ & Sig. \\
\hline Kemanfaatan & $0.311^{\mathrm{a}}$ & 0.097 & 0.093 & $0.000^{\mathrm{b}}$ \\
Kemudahan Pengguanaan & $0.237^{\mathrm{a}}$ & 0.074 & 0.071 & $0.000^{\mathrm{b}}$ \\
\hline
\end{tabular}


Berdasarkan hasil uji regresi ketiga sub variabel teknologi informasi diperoleh nilai Adjusted R Square untuk sub variabel kemanfaatan sebesar 0,097 dimana dapat dikatakan bahwa pengaruh kemanfaatan teknologi informasi terhadap kinerja aparatur nagari dalam pengelolaan keuangan nagari yaitu sebesar 9,3\%. Hal ini membuktikan bahwa sisanya sebesar 90,7 \% dipengaruhi oleh variabel lain. Selanjutnya untuk variabel kemudahan penggunaan diperoleh nilai Adjusted R Square sebesar 0,071 dimana dapat dikatakan bahwa pengaruh kemudahan penggunaan teknologi informasi terhadap kinerja aparatur nagari dalam pengelolaan keuangan nagari yaitu sebesar 7,1\%. Hal ini membuktikan bahwa sisanya sebesar 92,9\% dipengaruhi oleh variabel lain. Sementara itu di lihat dari hasil uji Anova pada hasil signifikansi yaitu menunjukkan angka 0,000 b hal ini membuktikan bahwa hasil uji regresi ini dapat dipercaya hingga $100 \%$ kebenarannya.

Berdasarkan penelitian mengenai pengaruh teknologi informasi terhadap kinerja aparatur nagari dalam pengelolaan keuangan nagari di Kabupaten Tanah Datar hal ini membuktikan bahwa terdapat pengaruh yang signifikan terhadap kinerja aparatur nagari dalam pengelolaan keuangan nagari di Kabupaten Tanah Datar. Hal ini baik di lihat secara simultan maupun secara sendiri-sendiri dari kedua variabel teknologi informasi yaitu kemanfaatan dan kemudahan penggunaan. Dari hasil pengolahan pengaruh kemanfaatan dan kemudahan penggunaan teknologi informasi terhadap kinerja aparatur nagari dalam pengelolaan keuangan nagari di Kabupaten Tanah Datar menunjukkan hasil signifikansi sebesar 0,000 dan nilai Adjust R Square sebesar 0,094 maka dengan begitu dapat dikatakan bahwa besar kontribusinya adalah $9,4 \%$ dan nilai $\mathrm{R}$ sebesar 0,318 yang berarti kekuatan dari variabel teknologi informasi terhadap kinerja aparatur nagari dalam pengelolaan keuangan nagari di Kabupaten Tanah Datar sebesar 31,8\%. Maka dalam hal ini dapat di tarik kesimpulan bahwa baik secara parsial maupun secara bersama-sama penerapan teknologi informasi memiliki pengaruh yang signifikan terhadap kinerja aparatur nagari dalam pegelolaan keuangan nagari di Kabupaten Tanah Datar.

Sementara itu berdasarkan hasil uji secara parsial pengaruh sub variabel kemanfaatan (X1) dan kemudahan (X2) terhadap kinerja aparatur pengelolaan keuangan nagari menghasilkan angka signifikansi masing-masing sebesar 0,000 dan nilai Adjust R Square untuk kemanfaatan sebesar 0,097 (9,7 \%) dan untuk kemudahan penggunaan sebesar 0,074 (7,4 \%). Maka dapat dikatakan bahwa kontribusi kemanfaatan teknologi informasi terhadap kinerja aparatur nagari dalam pengelolaan keuangan nagari sebesar 9,7\% dan kemudahan penggunaan teknologi informasi sebesar 7,4 \%.

Dengan melihat hasil penelitian ini dapat dipahami bahwa dari hasil penelitian ini dapat memperkuat dan membuktikan teori-teori dan penemuan penelitian yang ada, seperti yang dikemukakan oleh Goodhue dkk (dalam Azwir, 2010) bahwa penerapan teknologi informasi dapat memebrikan dampak positif terhadap kinerja individual yang mana apabila teknologi ini dapat dimanfaatkan dengan tepat dan mempunyai kecocokan dengan tugas yang dikerjakan. Kinerja yang semakin baik dan tinggi dalam hal ini ialah dalam pencapaian serangkaian tugas dengan menggunakan dukungan teknologi informasi. Kinerja yang semakin 
tinggi dalam melibatkan kombinasi dari efesiensi, efektifitas, produktifitas dan peningkatan kualitas.

Sementara itu hasil penelitian ini mendukung dan memperkuat teori yang dikemukakan oleh Thomson et al (dalam Mohammad Dian Fajri, 2011) bahwa pemanfaatan teknologi informasi ialah bertujuan untuk dapat menyelesaikan setiap tugas dan mampu meningkatkan kinerja. Dimana pemanfaatan teknologi informasi yang digunakan secara tepat dan didukung oleh keahlian personal dalam pengoperasiannya maka hal ini mampu meningkatkan kinerja indivdu tersebut. Dengan begitu penerapan teknologi informasi sangatlah mendukung dan meningkatkan kinerja dari setiap pegawai.

Selanjutnya hal ini juga mendukung teori yang dikemukakan oleh Amalia (dalam Alfa Alfredo Sembiring, 2016) bahwa teknologi informasi memiliki hubungan positif tetapi tidak signifikan antara beberapa faktor sosial, perasaan pengguna (Affect), konsekuensi jangka panjang dan kesesuaian tugas dalam pemanfaatan teknologi informasi terhadap kinerja individual, sedangkan berdasarkan kondisi yang memfasilitasinya berpengaruh positif serta memiliki hubungan yang negatif antara kompleksitas dalam pemanfaatan teknologi informasi terhadap kinerja individual.

Disamping itu hasil penelitian ini juga mendukung penelitian terdahulu yang dilakukan oleh Mohammad Dian Fajri (2011), Ririn Wiseliner (2013), Putu Pande Yudiastra (2015), Desak Made Arisuniarti (2016, Anis Nurlaili (2016) dan Mutia Sari dkk (2017) yang membuktikan bahwa penerapan teknologi informasi berpengaruh signifikan terhadap peningkatan kinerja. Namun dalam hal ini hasil penenlitian ini tidak menukung penelitian terdahulu yang dilakukan oleh Azwir Nazir dkk (2010) dan Rofika dkk (2014) yang membuktikan bahwa pemanfaatan teknologi informasi tidak berpengaruh signifikan terhadap kinerja.

\section{Penutup}

Berdasarkan hasil penelitian dan pembahasan yang telah diuraikan sebelumnya, maka dapat ditarik kesimpulan bahwa

1. Nilai Adjust R Square sub variabel kemanfaatan (X1) teknologi informasi terhadap kinerja aparatur nagari dalam pengelolaan keuangan nagari adalah sebesar 0,093 artinya hal ini dapat dikatakan bahwa kontribusi kemanfaatan teknologi informasi terhadap kinerja aparatur nagari dalam pengelolaan keuangan nagari di Kabupaten Tanah Datar adalah sebesar 9,3\% dan hasil nilai Adjust R Square sub varuabel kemudahan penggunaan (X2) teknologi informasi terhadap kinerja aparatur nagari dalam pengelolaan keuangan nagari adalah sebesar $0,071 \%$ artinya bahwa hal ini dapat dikatakan kontribusi kemudahan penggunaan teknologi informasi terhadap kinerja aparatur nagari dalam pengelolaan keuangan nagari di Kabupaten Tanah Datar adalah sebesar 7,1\%.

2. Pada angka signifikasi baik itu secara simultan maupun secara sendiri-sendiri pengaruh kemanfaatan dan kemudahan penggunaan teknologi informasi terhadap kinerja aparatur nagari dalam pengelolaan keuangan nagari menunjukkan angka sebesar 0,000. Hal ini menunjukkan bahwa nilai signifikansi lebih kecil dari 0,05 maka dapat dikatakan Ho ditolak dan $\mathrm{Ha}$ 
diterima. Dengan begitu dapat disimpulkan bahwa terdapat pengaruh yang signifikan variabel teknologi informasi terhadap kinerja aparatur nagari dalam pengelolaan keuangan nagari di Kabupaten Tanah Datar dan kebenaran hasil penelitian ini dapat dipercaya sampai $100 \%$.

Berdasarkan kesimpulan yang telah diuraikan, maka penulis mengemukakan saranyaitu dari hasil penelitian menunjukkan bahwa secara bersama sama sub variabel kemanfaatan dan kemudahan penggunaan teknologi informasi terhadap kinerja aparatur nagari dalam pengelolaan keuangan nagari di Kabupaten Tanah Datar dengan konstribusinya adalah sebesar 0,094 (9,4\%). Dapat dikatakan sisanya sebesar 90,6 \% masih belum dimaksimalkan oleh aparatur nagari di Kabupaten Tanah Datar. Dengan demikian dapat disarankan kepada semua aparatur nagari agar mampu meningkatkan keterampilannya di bidang teknologi informasi dan memaksimalkan penggunaan teknologi informasi dengan baik dan benar dalam meningkatkat kinerja dan juga tentunya agar tujuan peningkatan kinerja dapat tercapai hendaknya didukung dengan penambahan fasilitas yang lebih memadai.

\section{DAFTAR PUSTAKA}

\section{Buku dan Jurnal}

Alfa Alfrdo sembiring M. 2016. Pengaruh Penggunaan E-System dan Pemanfaatan Teknologi Informasi terhadap Kinerja Individual Aparatur Pajak. Artikel Ilmiah Mahasiswa

Rofika ardianto. 2014. Pengaruh Penerapan Akuntabilitas Keuangan, Pemanfaatan Teknologi Informasi, Kompetensi Aparatur Pemerintah Daerah dan Ketaatan Terhadap Peraturan Perundang-undangan terhadap kinerja Instansi Pemerintah. Jurnal Akuntansi (Volume 2 Nomor 2, April 2014)

Desak Made arisuniarti. 2016. Pengaruh Teknologi Informasi dan sistem Informasi Manajemen Terpadu Terhadap Kinerja Karyawan di Lingkungan Universitas Warmadewa. Jurnal Public Inspiration (Volume 3 Nomor 1 Tahun 2015)

Azwir Nazir dkk. 2010. Pengaruh Pemanfaatan Teknologi Informasi dan Pengendalian Intern Terhadap Kinerja Instansi Pemerintah (Studi Pada Satuan Kerja Daerah Kabupaten Kampar). Jurnal Akuntansi

Dimas Ernomo Putra. 2015. Pengaruh Kemudahan Terhadap Kemanfaatan, minat dan Penggunaan E-Commerce (Studi Kasus pada Pengguna Situs Olx.co.id. Jurnal Administrasi Bisnis (JAB) (Vol. 1 Nomor 2, April 2015)

Mangkunegara, A. 2011. Manajemen Sumber Daya Manusia Perusahaan. Bandung. PT.Remaja Rosdakarya

Mohammad Dian Fajri. 2011. Pengaruh Penggunaan Teknologi INformasi Terhadap Kinerja Karyawan Perusahaan Konsultan Perencana di Surakarta. Artikel Ilmiah Mahasiswa 
Anis Nurlaili. 2016. Pengaruh Pemanfaatan Teknologi Informasi dan Sistem Pengendalian Intern Terhadap Kinerja Instansi Pemerintah (Studi Pada Satuan Kerja Perangkat daerah (SKPD) Kabupaten Jember). Artikel Ilmiah Mahasiswa

Pasolong H. 2007. Teori Administrasi Publik. Bandung. Alfabeta.

Ririn wiseliner. 2013. Pengaruh Penerapan Teknologi Informasi terhadap Kinerja karyawan Pada PT. Serasi Autoraya track astra Rent A Car Cabang Pekanbaru. Skripsi Thesis. Universitas Islam Negeri sultan syarif Kasim Riau

Mutia Sari. 2017. Pengaruh Pemanfaatan Teknologi Informasi, Kompetensi Aparatur dan Komitmen Organisasi Terhadap Kinerja Manajerial Pengelolaan Keuangan Pada Satuan Kerja Perangkat Kabupaten, Pemerintahan Daerah Kabupaten Aceh Jaya. Jurnal Magister Akuntansi (Vol 6 No 2, Mei 2017)

Sri Maulidyah. 2016. Pengelolaan Keuangan dan Aset Desa dalam upaya Penguatan Kelembagaan Pemerintah Desa. Jurnal Pemerintahan, Politik dan Birokrasi (Vol 11 No 1 October 2016)

Syamsir.2017. "Model Pembinaan Aparatur Pemerintahan Nagari Dalam Pengelolaan Keuangan Nagari Di Kabupaten Tanah Datar Provinsi Sumatera Barat. Laporan Penelitian:Universitas Negeri Padang.

Putu Pnade Yudiastra. 2015. Pengaruh Penggunaan Teknologi Informasi, Disiplin Kerja, Insentif, Turnover terhadap Kinerja Pegawai. Jurnal Manajemen \& Bisnis (Vol 12 Nomor 1 Februari 2015)

\section{Peraturan Perundang-undangan}

Undang-undang Nomor 6 tahun 2014 Tentang Desa

Undang-undang No. 22 \& 25 Tahun 1999 jo UU No. 32 \& 33 Tahun 2004 Tentang Paket Kebijakan Otonomi Daerah

Instruksi Presiden Nomor 3 Tahun 2003 Tentang Kebijakan dan Strategi Nasional Pengembangan E-Government

Peraturan Menteri Dalam Negeri Republik Indonesia Nomor 113 Tahun 2014 Tentang Pengelolaan Keuangan Desa Pembaharuan dari Peraturan Menteri Dalam Negeri Republik Indonesia Nomor 37 Tahun 2007 Tentang Pedoman Pengelolaan Keuangan Desa

Peraturan Bupati Tanah Datar Nomor 11 Tahun 2014 Tentang Pedoman Pengelolaan Keuangan Nagari

Peraturan Daerah Kabupaten Tanah Datar Nomor 3 Tahun 2015 Tentang Perubahan Atas Peraturan daerah Nomor 4 Tahun 2007 Tentang Pokokpokok Pengelolaan Keuangan Daerah.

Peraturan Bupati Tanah datar Nomor 44 Tahun 2017 Tentang Visi Misi Badan Keuangan dalam Pengelolaan Keuangan Daerah 